\title{
Van İli Merkez İlçede Küçükbaş Hayvancılı Faaliyetleri ve Genel Sorunlar: I. İşletmelerin Yapısal Özellikleri
}

\author{
Aşkın YILDIZ ${ }^{1}$, Turgut AYGÜN ${ }^{* 2}$ \\ ${ }^{1}$ Van Yüzüncü Y1l Üniversitesi, Fen Bilimleri Enstitüsü, Zootekni Anabilim Dalı, 65080, Van, Türkiye \\ ${ }^{2}$ Van Yüzüncü Yıl Üniversitesi, Ziraat Fakültesi, Zootekni Bölümü, 65080, Van, Türkiye
}

Aşkın YILDIZ, ORCID No: 0000-0003-0939-8919, Turgut AYGÜN, ORCID No: 0000-0002-0694-6628

\begin{tabular}{|c|c|}
\hline MAKALE BİLGís İ & ÖZ E T \\
\hline Araştırma Makalesi & \multirow{12}{*}{ 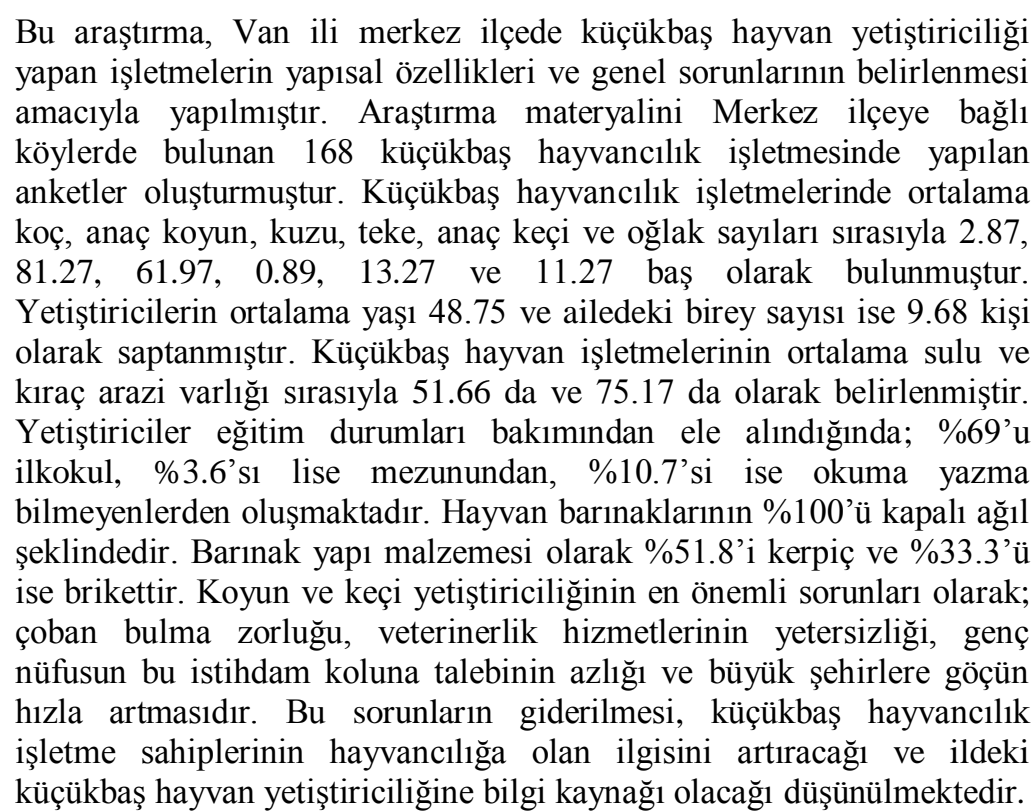 } \\
\hline $\begin{array}{l}\text { Bu makale, birinci yazarın tezli } \\
\text { yüksek lisans tezinin bir bölümünden } \\
\text { özetlenmiştir. }\end{array}$ & \\
\hline Geliș: 04.03.2021 & \\
\hline Kabul & \\
\hline Anahtar Kelimeler & \\
\hline Aile işletmeleri & \\
\hline Küçükbaş hayvancılık & \\
\hline & \\
\hline ellikler & \\
\hline Yetiştirici sorunları & \\
\hline * Sorumlu Yazar & \\
\hline turgutay & \\
\hline
\end{tabular}

\section{Activities of Small Ruminant Husbandry and General Problems in Van Central District: I. Structural Features of Enterprises}

\section{ARTICLE INFO}

\section{Research Article}

This article is summarized from part of the first author's master's thesis.

Received : 04.03.2021

Accepted : 11.06.2021

\section{Keywords}

Family enterprises

Farmer problems

Small ruminant husbandry

Structural features

Van

\section{ABSTRACT}

This research was performed to determine the structural features of small ruminant husbandry enterprises and their general problems in central district of Van. Research material has been created 168 small ruminant firms in the villages of the central district of Van. The numbers of ram, sheep, lamb, buck, goat and kid were found in enterprises of small ruminants $2.87,81.27,61.97,0.89,13.27$, and 11.27 , respectively. The mean age of the breeders was determined as 48.75 and the number of family members is 9.68 person. The average irrigated and dry lands of small ruminant farms were found 51.66 ha and 75.17 ha, respectively. When the breeders are considered in terms of their education status; $69 \%$ of them are primary school graduates, $3.6 \%$ are high school graduates and $10.7 \%$ are illiterate. All of the animal shelters are in the form of closed halo. As shelter building material was used with 51.8\% ratio of mud brick and $33.3 \%$ rate with the brick. The most important 


\section{* Corresponding Author}

turgutaygun@hotmail.com problems of sheep and goat husbandry are the difficulty of finding shepherd, lack of veterinary services, lack of demand for field this operation of young people and the increase of migration to big cities. It is thought that eliminating these problems will increase the interest of the owners of small ruminant breeding farms and will be a source of information for sheep and goat husbandry in the province.

\section{Giriş}

Hayvancılık ülke ekonomisi ve tarım sektörü içerisinde önemli bir yere ve potansiyele sahiptir. İnsanların fizyolojik ihtiyaçlarını karşılama özelliğinden dolayı yeterli ve dengeli beslenmenin sağlanması yanında ekonomik kalkınma için gerekli sermayenin elde edilmesi açısından da önemlidir. Her türlü hayvansal üretim faaliyetleri, bitkisel ürün ve yan ürünlerinin değerlendirilmesi, işgücü etkinliğinin artırılması, doğal ve ekonomik koşullardan kaynaklanan risklerin azaltılmasında rol oynayarak işletme kârlılığına olumlu katkılar sağlamaktadır (Vural ve Fidan, 2007). Bir ülkenin gelişmişlik düzeyi ne olursa olsun gıda maddeleri üretimini garanti altına alması gerekmektedir. Gelecekte gida maddelerinin temininde sorun yaşanmaması için bu alanda milli bir tarım politikası oluşturulması zorunludur. Hayvancılık için büyük bir potansiyele ve iklim yapısına sahip olan Türkiye'de üreticiler, yıllardan beri gelen alışkanlıkları gereği, kendi kendine yeterliliği benimseyen kapalı bir üretim sistemi modeli içerisinde, hayvansal ürün ihtiyacını karşılama çabasında olmuşlardır.

Küçükbaş hayvan yetiştiriciliği, iklim ve arazi yapısı dolayısıyla bitkisel üretime uygun olmayan, sığırlar tarafından değerlendirilemeyen zayıf mera ile nadas, anız ve bitkisel üretime uygun olmayan alanları değerlendirerek insan tüketimine hazır et, süt, yapağı, k1l, tiftik ve deri gibi ürünlere dönüştüren bir hayvancıllk faaliyetidir. Küçükbaş hayvanlar yeme karşı kanaatkâr olduğundan çoğu kez yalnız mera ile yetinebilmektedirler. Ülkemizin kendine özgü doğal kaynaklarının, özellikle çayır ve meraların koyun ve keçilere uygun oluşu ve kırsal kesimdeki ailelerin tüketim alışkanlıkları koyun ve keçi yetiştiriciliğini tarımsal yapı içersinde önemli bir yer tutmasına olanak sağlamıştır. Bugün koyun ve keçi türü dünyanın çeşitli yerlerinde birbirinden farklı çevre koşullarında çok geniş bir yaşama alanı bulmakta ve yetiştiriciye önemli gelir sağlamaktadır. Özellikle de kötü çevre koşullarına dayanıklı hayvan olmaları gelişmemiş ve az gelişmiş ülkelerin küçük ve orta ölçekli işletmelerinin en tercih ettiği hayvan türleridirler. Türkiye'nin kırmızı et üretiminin \%20.92'si, süt üretiminin ise \%7.38'i koyun ve keçiden elde ediliyor olması bunun sonucudur (Kaymakçı, 2006; Anonim, 2020a).

Dellal ve ark. (2002a) Güneydoğu Anadolu Projesi (GAP) Bölgesinde küçükbaş hayvan yetiştiriciliğin yapısal özelliklerini inceledikleri çalışmalarında, bölgede küçükbaş hayvan yetiştiriciliği büyük oranda (\%98.9) köyde yerleşik, (\%15.1) yaylacılık şeklindeki üretim tarzında yapıldığını, barınakların büyük oranda (\%88.4) şahıs malı ve eve bitişik ya da evin yanında yer aldığını, meraları köy merkezine yakın köy ortak malı olduğunu, otlatma dışındaki yem kaynaklarını tane yem (\%100), saman (\%100), anız (\%80.5), fabrika yemi (\%100) ve silaj (\%0.4) oluşturduğunu, çobanlar genellikle aile içerisinden temin edildiğini, koyun ve keçilerde aşım dönemi başlangıç ve bitiş tarihlerinin Haziran-Temmuz; AğustosEylül ve Ağustos-Ekim; Ekim-Kasım ayları olduğunu, kuzu doğumlarının Kasım-Şubat ve 
Ocak-Mart aylarında başladığını, sütten kesim yaşı kuzu ve oğlaklar için ortalama 3.2 ve 3.3 ay olduğunu, işletmelerin tamamı koyunlarını kırkarlarken, keçilerini kırkan işletmelerin oranı \%60.6 olduğunu, işletmelerin tamamının sürülerinde koruyucu aşı yaptırmakta olduğunu ortaya koymuşlardır.

Dellal ve ark.'nın (2002b) GAP bölgesinde yaptıkları araştırmaya göre; işletmelerin \%92.4'ü üretilen sütü aile içinde ve pazara yönelik olarak değerlendirdikleri, üretilen bu sütün (\%82.9) peynir formunda pazara arz edildiği bildirilmektedir. GAP Bölgesi küçükbaş hayvancılık işletmelerinde gerek hayvansal üretim değeri, gerekse gayri safi üretim değeri içerisinde süt üretimin payının diğer ürünlerden daha yüksek olduğu bildirilmiştir. İşletmelerin \%66.4'ü süt ve süt ürünlerinin pazarlanmasında daha çok aracilardan yararlandıkları bu durumun ise küçükbaş hayvan yetiştiricilerinin elde edecekleri kar oranlarının düşük olmasına neden olacağı bildirilmektedir. Araştırmanın yürütüldüğü illerde esas olarak süt üretimine yönelik koyun ve keçi yetiştiriciliğinin yoğunlaştığı ilçe ve köylerde özellikle yetiştirici örgütlerinin de devreye girmesiyle sütün üretilmesi, değerlendirilmesi ve pazarlanmasında yetiştiriciler daha etkin ve karlı hale getirilebileceği bildirilmektedir. İncelenen işletmelerin büyük çoğunluğu (\%93.2) koyun ve keçi gübresini aile içinde değerlendirdikleri belirlenmiş olup, pazarlayan işletmelerin oranı $\% 0.8$ 'dir. Küçükbaş hayvancılık işletmelerinin \%76.5'inde damızlık fazlası erkek ve dişi hayvanları besiye alarak değerlendirebildikleri gibi işletmelerin büyük çoğunluğunun düzenli olarak kuzu-oğlak ve/veya toklu-çepiç besisi yapmadıkları bildirilmiştir. Bu nedenle işletmeler damızlık fazlası kuzu ve oğlaklarını besiye almadan besicilere veya kasaplara pazarlayabildikleri gibi kendileri de besiye aldıktan sonra canlı olarak pazarlayabildikleri bildirilmektedir.

Van ili merkez ilçeye bağlı bazı köylerde gerçekleştirilen bu anket çalışmasının amaçları; küçük aile işletmeleri biçiminde şekillenen işletmelerin genel yapısal özellikleri ve koyun-keçi yetiştiriciliğginin bu işletmelerdeki yerini belirlemek, küçükbaş hayvan yetiştirme etkinlikleri çerçevesinde oluşan işbirliği alışkanlıklarının kimi ayrıntılarını ve işletmelerde ekstansif yetiştirme koşullarının duyarlı bir tanımını ortaya koymak şeklinde sıralanabilir. $\mathrm{Bu}$ çalışmanın, bölge küçükbaş hayvancılığının tanıtımı bakımından bir kaynak özelliği taşıyacağı ve sorunların çözümüne yönelik alınacak önlemlerin oluşturulması konusunda yön verici olacağ düşünülmektedir.

\section{Materyal ve Yöntem}

\section{Materyal}

Van ili Merkez ilçeye bağlı Aşit, Bakraçlı, Beşçatak ve Gövelek köyleri; Erçek beldesi Merkez ve Ağzıkara, Arıtoprak, Aşağı Gölalan, Yukarı Gölalan, Çalımlı, Değirmenarkı, Ilıkkaynak, Karagündüz, Karakoç, Kaymaklı, Kozluca, Ortanca, Yatıksırt ve Yukarıgüneyce köyleri; Timar beldesine bağlı Ağartı, Akçaören, Alaköy, Arısu, Atmaca, Bağdaşan, Çolpan, Değirmenözü, Dilimli, Ermişler, Gedikbulak, Güvençli, Halkalı, Kolsatan, Kumluca, Mollakasım, Ocaklı, Pirgarip, Tabanlı, Topaktaş, Yeniköşk ve Yeşilsu köyleri olmak üzere toplam 41 yerleşim yerinde şansa bağl1 olarak seçilmiş toğlam 168 küçükbaş (koyun-keçi) hayvancılık işletmesi araştırmanın materyalini oluşturmuştur. İncelenen işletmelerin 74'ü Erçek beldesi köylerinden, 21'i Merkez ilçe köylerinden, 73'ü Timar beldesi merkezine bağlı köylerden oluşmaktadır. Düzenlenen bir anket formu yoluyla işletme sahipleri ile yüz yüze 
görüşülerek, işletmelerin küçükbaş hayvancılık faaliyetleri ve genel sorunlarına ilişkin veriler toplanmıştır (Tablo 1).

Tablo 1. İncelenen işletmelerin belirlenen merkezlere göre dağ 11 ımı

Table 1. Distribution of the enterprises examined according to the centers

\begin{tabular}{lcc}
\hline İşletmeler & İşletme Sayısı & İşletme Oranı (\%) \\
\hline Erçek & 74 & 44.0 \\
Merkez & 21 & 12.5 \\
Timar & 73 & 43.5 \\
Toplam & 168 & 100.0 \\
\hline
\end{tabular}

\section{Araștırma alanının tanıtımı}

Van ili Doğu Anadolu Bölgesinin Yukar1-Murat Van bölümünde $42^{\circ} 40^{\prime}$ ve $44^{\circ} 30^{\prime}$ doğu boylamları ile $37^{\circ} 43^{\prime}$ ve $39^{\circ} 26^{\prime}$ kuzey enlemleri arasında yer alan Van gölü kapalı havzasındadır. Kuzeyde Ağrı ili, Doğubayazıt, Diyadin ve Hamur İlçeleri; batıda Van gölü ile Ağrı ilinin Patnos ilçesi, Bitlis ilinin Adilcevaz, Tatvan ve Hizan ilçeleri; güneyde Siirt'in Pervari; Hakkâri ilinin, Beytüşşebap ve Yüksekova ilçeleri ile komşudur. Van'ın merkezi, kuzeyden, doğudan ve güneyden dağlarla çevrilmiş Van Gölünün doğu kıyısına $5 \mathrm{~km}$ uzaklıkta, göle doğru eğimli ova üzerine kurulmuştur. Merkez ilçe doğuda Özalp ilçesi, batıda Van Gölü, kuzeyde Muradiye ve Erciş ilçeleri, güneyde Gürpınar, Gevaş ve Çatak ilçeleri ile çevrilidir. $19.069 \mathrm{~km}^{2}$ lik il alanı, göl alanı dâhil $21.003 \mathrm{~km}^{2}$ yüzölçümü ile Türkiye topraklarının \%2.5'ini oluşturur. Merkez ilçenin yüzölçümü $2.739 \mathrm{~km}^{2}$, denizden yüksekliği 1725 m'dir. Merkez ilçenin 2 belediye, 28 mahalle, 2 bucak, 90 köy, 34 mezrası olmak üzere 156 yerleşim birimi vardır (Anonim, 1998; Anonim, 2020b). Van'da hayvancılığın temel sektör olmasında il arazisinin \%70'inden fazlasının çayır-mera olmasının payı büyüktür. Arazi yapısı, özellikle küçükbaş hayvan yetiştiriciliğine oldukça elverişlidir (Anonim, 2020b).

Van ve çevresinde karasal iklim hüküm sürer. Kışlar özellikle çok uzun, şiddetli ve karlıdır. Kışın yaklaşık 150 güne yakın $0^{\circ} \mathrm{C}$ 'nin altında geçer. Yağan kar 3 aya yakın yerde kalır. Yazlar ise kısa ve sıcak geçer. En soğuk ve en sıcak ay ortalaması arasındaki sıcaklık fark1 $25^{\circ} \mathrm{C}$ 'dir. Yıllık sıcaklık ortalaması 9 derece yılın en soğuk ayı olan Ocak ortalaması $3.6{ }^{\circ} \mathrm{C}$, Temmuz ayı ortalaması ise $22^{\circ} \mathrm{C}$ civarındadır. Yıllık yağış ortalaması $370-570 \mathrm{~mm}$ arasında değişir. Yağışın en fazla olduğu mevsim ilkbahar (\%39), bunu kış mevsimi (\%26.6) ve sonbahar (\%27.2) izler. En az yağış yaz mevsiminde görülür. Van Gölü çevresinde, kışların uzun ancak nispeten daha az soğuk geçtiği, baharların kısa sürdüğü, yazın ise çok sıcak olmamakla birlikte kurak geçtiği bir iklim yaşanır. Araştırma merkezini oluşturan Van merkeze ilçeye ait yüzölçümü 214.948 ha, tarım arazisi 75.346 ha, çayır mera alanı 114.956 ha ve tarım dış1 24.646 ha'dır (Anonim, 1998).

\section{Yöntem}

Araştırmanın materyali olan 168 işletmeden araştırmacılar tarafindan anketle toplanan veriler, üzerinde durulan özelliklerden sürekli değişkenler için tanımlayıcı istatistikler; ortalama, standart hata, minimum ve maksimum değerler olarak ifade edilirken, kategorik değişkenler için sayı ve yüzde olarak ifade edilmiştir. Sürekli değişkenler bakımından eğitim durumu grupları arasında fark olup olmadığını belirlemek amacıyla tek yönlü varyans analizi 
(ANOVA) yapılmıştır. Kategorik değişkenler arasındaki ilişkiyi belirlemede Ki-kare testi yapılmıştır. Hesaplamalarda istatistik önemlilik düzeyi \%5 olarak alınmış ve hesaplamalarda SPSS (2013) istatistik paket programı kullanılmıştır.

\section{Bulgular ve Tartışma}

Van ili Merkez ilçeye bağlı köylerde küçükbaş hayvan yetiştiriciliği yapan işletme sahipleriyle yapılan görüşmeler sonucunda, işletme yapıları ve genel sorunları hakkında bilgiler alınmıştır.

\section{İsletmelerin genel özellikleri}

Van İli merkez ilçede küçükbaş hayvan yetiştiricilerinin öğrenim durumuna göre; işletmecilerin eğitim durumları bakımından önemli bir kısmını \%69.0 ile ilkokul mezunları oluştururken, \%10.7'si okuma yazma bilmeyenlerden ve \%11.3'ünü okula gitmeden okuma yazma bilenlerden, \%5.4'ünün ortaöğretim ve \%3.6'sının lise mezunlarından oluştuğu saptanmıştır (Tablo 2).

Tablo 2. İşletmelerin genel özellikleri

Table 2. General features of the enterprises

\begin{tabular}{clcc}
\hline \multicolumn{1}{c}{ Özellikler } & & $\mathrm{n}$ & $\%$ \\
\hline & Okuma yazma bilmeyen & 18 & 10.7 \\
& Okur yazar & 19 & 11.3 \\
Ĕ̈itim durumu & İlkögrenim & 116 & 69.0 \\
& Orta öğrenim & 9 & 5.4 \\
& Lise & 6 & 3.6 \\
\hline & Mülk & 139 & 82.7 \\
& Kira & 6 & 3.6 \\
Arazi Varlığ1 & Hem kira hem mülk & 4 & 2.4 \\
& Arazisi yok & 19 & 11.3 \\
\hline \multirow{5}{*}{ Çoban sayısı (kişi) } & 2 & 84 & 50.0 \\
& 2 & 77 & 45.8 \\
& 4 & 5 & 3.0 \\
Çoban durumu & Aileden & 2 & 1.2 \\
& Geçici & 25 & 14.9 \\
& Sürekli & 97 & 57.7 \\
\hline
\end{tabular}

Okuma yazma bilmeme oranı Türkiye ortalamasından (\%6.4) yüksek bulunmuştur. Yetiştiricilerin eğitim durumları bakımından ağırlıklı olarak ilkokul mezunu oluşturmaktadır. Ortaokul ve lise mezunları oranları oldukça düşüktür. Elde edilen bulgulara göre üreticilerin büyük bir çoğunluğunun eğitim düzeyi düşük kişilerden oluştuğu bu durumun ise tarımsal yeniliklerin benimsenmesinde ve teknolojik gelişmelerin tarımsal faaliyete aktarılmasında olumsuz etkiye neden olacağı ve eğitim düzeyinin yükseltilmesi gerektiği gerçeğini ortaya koymaktadır. Koyuncu ve ark.'nın (2006) Çanakkale'de yaptıkları çalışmada elde edilen sonuçlarda \%65 ilkokul, \%10 ortaokul ve \%25 lise mezunu olduğu belirtilmektedir. Bu durum Çanakkale yöresindeki yetiştiricilerin eğitim düzeyinin daha iyi olduğunu göstermektedir. 
Başka bir çalışmada Aksoy ve Yavuz (2008), Doğu Anadolu Bölgesinde Erzurum, Ağrı, Van ve Elazığ illerinde yaptıkları araştırmada Van için okuma yazma bilmeyenlerin oranını \%12.3, okur yazar \%10.4, ilkokul \%67, ortaokul \%8.5 ve \%0.9 lise mezunu olduğunu belirtmiştir. Yapılan bu araştırma ile benzerlik gösteren çalışmalardan da anlaşılacağı gibi küçükbaş hayvan yetiştiricilerinin mesleki eğitimden uzak, eğitim oranı düşük kişilerden oluştuğu sonucu ortaya çıkmaktadır.

Arazi varlı̆̆ bakımından yapılan değerlendirmede küçükbaş hayvan işletmelerinin arazi varlıklarını \%82.7'sinin kendi arazisi, \%2.4'ünün kira ve kendi arazisi ve \%11.3'ünün arazisi olmayan işletmelerden oluştuğu, ortalama sulu arazi büyüklüğünün 51.66 da, ortalama susuz arazi büyüklüğünün ise 75.17 da olduğu tespit edilmiştir. Hiç arazisi olmayan işletmelerin de başarılı bir yetiştiricilik yapabildiği gözlemler arasındadır. Sulu arazi büyüklüğü 2 ile 500 da, susuz arazi büyüklüğü ise 7-700 da arasında değiştiği belirlenmiştir. Bilginturan (2008) Burdur ili Damılık Koyun Keçi Birliği üyesi yetiştiricilerini kapsayan araştırmasında, keçicilik işletmelerinin arazi varlıkları bakımından \%87.5'ini kendi arazisi, \%2.5'inin kira ve kendi arazisi ve \%10'un arazisi olmayan işletmelerden oluştuğu bulgusu yapılan bu araştırma ile benzerlik göstermektedir. Araştırma sonucunda ortalama arazi varlığına ait elde edilen değer Karaca ve ark. (1993) tarafindan bildirilen ortalama arazi varlığ1 olan 116.2 da ve Dayan'ın (2007) ortalama 137.61 da değerlerinden düşük, Bilginturan'ın (2008) bildirdiği ortalama arazi varlığ olan 40.31 da değerinden ise oldukça yüksektir. Ayrıca Kaymakçı ve ark.'nın (1998) işletmelerin arazi varlığı ortalamasını 110 da bulgusundan düşük bulunmuştur. Bu değerlere bakıldığında ilin hayvansal üretim için yeterli kaba yem ihtiyacını karşılayacak arazi varlı̆ına sahip olduğu söylenebilir.

Deniz (2009) Hakkari'de koyunculuk yapan işletmeleri kapsayan araştırmasında işletme başına düşen arazi miktarının 7.44 da olduğu, bunun \%63.6'sının çayır-mera arazisi olduğu, laktasyon süt veriminin $50 \mathrm{~kg}$, işletmelerin verim düzeylerinin düşük ve küçük ölçekli işletmeler olduğunu bildirmiştir. Hayvan başına düşen verimin yükseltilmesi bakımından; yem bitkileri ekim alanlarının arttırılması, yem miktarı ve kalitesinin uygun olması, bakım ve besleme koşullarının iyileştirilmesi, hastalıklarla mücadele yöntemleri konusunda çiftçilerin bilgilendirilmesi ve veteriner hizmetlerinden çiftçilerin yararlanma koşullarının iyileştirilmesi gerektiği ortaya konulmuştur.

Küçükbaş hayvan yetiştiriciliğindeki temel taşlardan olan çoban ihtiyacını karşılamak için, birkaç sürü sahibi bir araya gelerek para ya da kuzu karşıllı̆ında çoban tutarak hayvanlarını otlatırlar. Bu şekilde ortak sürü oluşturarak meralardan daha etkin şekilde yararlanılır. Çobanın aileden olma durumu düşüktür. Çünkü ailenin genç fertleri ya eğitim için ya da aile ekonomisine katkıda bulunmak için büyük şehirlere göç etmektedirler. Dolayısıyla gençler hayvan yetiştiriciliğine uzak kalmaktadır. Bu şekilde gençlerin il içi veya il dışı göçleri aile işletmeciliğini olumsuz etkilemektedir. Elde edilen bulgulara göre çobanın aileden olma durumu \%14.9, dışarıdan geçici ve ücretli olma durumu \%57.7 ve sürekli olma durumu \%27.4'dür. Çoban sayısı bakımından küçükbaş hayvancıllk işletmelerinde çoban bulundurma oranları $\% 50$ oranında bir kişi, $\% 45.8$ oranında iki , $\% 3.0$ oranında üç ve $\% 1.2$ oranında dört kişidir. Sürüdeki hayvan sayısı artıkça çoban sayısı da artmaktadır. Karaca ve ark. (1993), Doğu Anadolu Bölgesi koyunculuğunda çoban kullanımının sadece gerçek anlamda meralardan yaralanma döneminde yapılmakta olduğunu, ortak sürülerin Mayıs-Ekim aylarını kapsayan 5-6 aylık dönemde otlatıldıkları belirtilmektedir. Koyun veya kuzu sürüleri 
için çoban sayılarını, başlıca sürü büyüklüğü ve çoban olacak kişilerin durumuna bağlı olarak 1 veya 2 kişiden oluştuğunu belirterek, çoban kullanım dönemi ve kullanılan çoban sayısı açısından araştırmamızla benzerlik göstermekte olduğu belirlenmiştir. Bu bulgular Koyuncu ve ark.'nın (2005) Güney Marmara Bölgesi Keçicilik İşletmelerinin tek bir çoban bulundurma belirlemesine yakın ve çobanın aile fertlerinden oluştuğu belirlemesinden ise farklılık göstermektedir. Kaymakçı ve ark.'nın (1998) Doğu Anadolu Bölgesi'nde ortak sürü oluşturularak, ortak çoban tutmanın yaygın olduğunu, işletmeler içinde ferdi çoban tutmanın az olduğunu saptadıkları araştırma bulguları ile benzerlik göstermektedir. Başka bir araştırmada, Doğu Anadolu koyunculuk işletmelerinde ortak sürülerin bir-iki çoban tarafından idare edildiğini bildirdikleri anket bulgularıyla da benzer bulunmuştur (Karaca ve ark., 1996). $\mathrm{Bu}$ araştırmada elde edilen sonuca göre çoban temini konusunda aile işgücü kaynaklarının kullanımının sınırlı olduğu söylenebilir. Özellikle işletme sahiplerinin çoğunun Van il merkezinde de evlerinin bulunuyor olması ve çocukların eğitimlerini il merkezinde tamamlama isteği, yetiştiricilikte aile işgücünden faydalanmayı azaltmakta, okumayan gençlerin ise Van merkez veya büyük şehirlere çalışmaya gitmeyi tercih etmektedirler. Bu nedenlerden dolayı, çoban bulma sorun haline gelmektedir. Çoban bulma sorunu beraberinde çobanlık ücretlerini de artırmaktadır. Çoban temini sorununu ortadan kaldırmak için bir kaç küçük işletmenin bir araya gelerek ortak sürü oluşturmasını zorunlu kılmaktadır. Küçükbaş hayvan yetiştiriciliğinin önemli unsurlarından biri olan çobanlığa bir meslek özelliği kazandırmak ve özendirmek için gerekli kurum ve kuruluşların uygun eğitimler ve çalışmalar yaparak, bu alana ilginin artırılmasına çalışılmalıdır. Küçükbaş hayvan işletmelerinin meraya \%15.5 oranında tek aile sürüsü şeklinde çıktıkları ve döndükleri saptanmıştır. Ortak sürü oluşturarak meraya çıkan işletmelerin oranı $\% 84.5$ 'tir.

\section{İsletmelerin yapısal durumu}

İşletmelerin bazı yapısal özelliklerine ilişskin sonuçlar Tablo 3'de verilmiştir.

Tablo 3. İşletmelerin yapısal durumu

Table 3. Structural situation of the enterprises

\begin{tabular}{|c|c|c|c|c|c|}
\hline & & $\mathrm{n}$ & En az & En çok & Ortalama \\
\hline \multicolumn{2}{|c|}{ İşletmeci yaşları } & 168 & 21 & 80 & $48.75 \pm 0.87$ \\
\hline \multicolumn{2}{|c|}{ Hane birey sayısı } & 168 & 2 & 24 & $9.68 \pm 0.28$ \\
\hline \multirow{2}{*}{$\begin{array}{l}\text { Arazi } \\
\text { durumu(da) }\end{array}$} & Sulu & 90 & 2 & 500 & $51.66 \pm 7.54$ \\
\hline & Susuz & 130 & 7 & 1000 & $75.17 \pm 10.94$ \\
\hline \multirow{2}{*}{$\begin{array}{l}\text { Ekilen } \\
\text { alan(da) }\end{array}$} & Sulu & 87 & 2 & 500 & $47.95 \pm 7.40$ \\
\hline & Susuz & 120 & 7 & 700 & $55.06 \pm 7.06$ \\
\hline \multirow{6}{*}{$\begin{array}{l}\text { Hayvan } \\
\text { sayıları (baş) }\end{array}$} & Koç & 168 & 0 & 10 & $2.87 \pm 0.21$ \\
\hline & Anaç koyun & 168 & 0 & 620 & $81.27 \pm 5.94$ \\
\hline & Kuzu(dişi-erkek) & 168 & 0 & 350 & $61.97 \pm 4.50$ \\
\hline & Anaç keçi & 168 & 0 & 90 & $13.27 \pm 1.11$ \\
\hline & Teke & 168 & 0 & 5 & $0.89 \pm 0.09$ \\
\hline & Oğlak(dişi-erkek) & 168 & 0 & 70 & $11.27 \pm 0.92$ \\
\hline
\end{tabular}


Tablo 3'e göre anket kapsamında görüşülen işletmecilerde yaş 21 ile 80 arasında olup ortalama 48.75 yıldır. Bu durum üreticilerin büyük bir kısmının orta ve üst yaş gurubunda olduklarını göstermektedir. Bu ortalamanın, Bilginturan'ın (2008) Burdur ilinde yaptığ 1 araştırmada koyunculuk işletmelerinde çalışanların yaşlarının ise 22-80 arasında (ortalama 46.74) değiştiği ve keçicilik işletmelerinde çalışanların yaşlarının ise 30-69 arasındaki (ortalama 50.30) yaş değerlerine yakın olduğu bulunmuştur. Koyuncu ve ark.'nın (2006) yaptıkları çalışmada işletmelerde çalışanların yaşlarının ortalama 47 sonucu ile yapılan bu anketin sonucu uyum göstermektedir.

Anket yapılan 168 işletmede hane halkı sayısı ağırlıklı olarak 2-24 aralığında ve ortalama 9.68 kişiden oluştuğu bulgusu, Deniz (2009)'in Hakkari ilinde yaptığı çalışmada ortalama hane halkı sayısının 9.9 kişi olduğu bulgusu ile Dayan'ın (2007) Norduz bölgesi yetiştiricilerinin ortalama hane halkı sayısı olan 8 kişilik değerine yakın bulunmuştur. Ancak Bilginturan'nın (2008) Burdur'da yaptığı çalışmadan elde edilen 3 kişi değerinden ise daha yüksek bulunmuştur. Araç'ın (2007) yaptığı çalışmada isletmelerdeki aile nüfusu ortalaması olan 5.75 değeri ise araştırmadaki değerden düşüktür. Ayrıca elde edilen bu sonuç Türkiye ortalama hane halkı sayısından (4.50) daha yüksek bulunmuştur. Elde edilen sonucun yüksek çıkmasında evlenen erkek evladın da eş ve çocuklarıyla beraber aynı evde ikamet ediyor olmasından kaynaklandığ 1 düşünülmektedir.

Küçükbaş hayvan işletmelerinin ortalama sulu arazi varlığ 51.66 da, ortalama susuz arazi varlığ 1 ise 75.17 da olarak belirlenmiştir. Ekilen sulu arazi büyüklükleri 2 ile 500 da, susuz arazi ise 7 ile 700 da değişim aralığında olduğu tespit edilmiştir.

İncelenen işletmelerde mevcut hayvan varlığı dağılımına göre; kimi işletmelerde hiç koyun yok iken kimi işletmelerde 620 baş anaç koyun bulunmaktadır. Ortalama olarak anaç koyun sayısı 81.27 baş kadardır. Koç sayısı işletme başına ortalama 2.87 baştır. Kuzu varlığı değerlendirilirken cinsiyet ayrımı yapılmaksızın tümü birlikte değerlendirilmiştir. Ortalama dişi ve erkek kuzu sayısı ise ortalama 61.97 baş olduğu görülmektedir. Küçükbaş hayvancılık işletmelerinde ortalama anaç keçi sayısı 13.27'dir. Anaç keçi sayısının 0'dan 90 başlık anaç sürü büyüklügüüne ulaşabildiği belirlenmiştir. Yine bu işletmelerde teke sayısı ortalama 0.89 , dişi-erkek oğlak sayısı ise ortalama 11.27 baş olduğu görülmüştür. Koyun sürülerinin tamamına yakınında sınırlı sayıda da olsa keçi varlığından söz edilebilir. Yalnızca keçi varlığına sahip sürü oranının sınırlı sayıda olduğu da tespit edilmiştir. İşletmelerin hayvan varlığı birçok etmenin etkisi altındadır. Bunlar arasında kaba yem üretimi olanakları, işletmenin maddi gücü, köyün mera miktar ve kalitesi sıralanabilir (Karaca ve ark., 1993). Söz konusu ortalama koyun sayısı değerleri, Karaca ve ark.'nın (1996) Doğu Anadolu bölgesinde yaptığ 1 çalışmada elde ettiği, ortalama koyun sayısı olan 59 baş değerinden oldukça yüksek; Günal'ın (2006) Tekirdağ koyunculuk işletmelerinde bulduğu ortalama koyun sayısı olan 123 değerinden oldukça düşük bulunmuştur. Dellal ve ark.'nın (2002a) Diyarbakır, Şanlıurfa, Gaziantep ve Adıyaman illerinde incelenen küçükbaş hayvancılık işletmelerinde koyun ve keçi sayıları ortalama olarak sırasıyla 90.9 ve 43.3 baş, 152.9 ve 28.8 baş, 85.6 ve 30.0 baş ve 92.3 ve 47.3 baş olarak elde ettikleri değerlerden ise düşük bulunmuştur. Genel olarak küçükbaş hayvan sürüsünün büyük bir çoğunluğunu koyun oluşturmaktadır. Meraların keçi yetiştiriciliğine uygun olmaması sürüdeki koyun sayısını artıran sebeplerden biridir. Sürü içerisinde az da olsa muhakkak keçi bulundurulmaya çalışıldığı tespitler arasındadır. Keçi yetiştiriciliği sağlık açısından değeri bilinen keçi sütü ve sürü yönetimindeki fonksiyonu 
nedeniyle tercih edilmektedir. Araştırma sonunda ortaya çıkan hayvan sayısı bakımından işletmelerin, küçük aile işletmeleri şeklinde şekillendiği tespit edilmiştir. Dolayısıyla mevcut işletme büyüklüğü ile işletmelerin hayvancılıktan elde edecekleri gelir ile geçinmeleri mümkün görünmemektedir.

Doğu Anadolu Bölgesinde, bitkisel üretim açısından hayati öneme sahip olan hayvan gübresi yakacak olarak kullanılmaktadır. İncelenen küçükbaş hayvan işletmelerinde hayvan gübrelerini (\%76.2) oranında yakacak olarak kullandıkları, gübre olarak kullananların oranı (\%8.3) iken pazarlayarak değerlendirenlerin (\%1.2) oranı oldukça düşüktür. Dellal ve ark. (2002b) yaptıkları çalışmada koyun keçi yetiştiricilerinin çoğunluğu hayvan gübresini (\%93.2 oranında) işletme içinde değerlendirdiklerini, ticari olarak pazarlayanların oranını ise $\% 0.8$ olduğunu bildirmişlerdir.

\section{Barınak özellikleri}

İşletmelerin barınak özelliklerine ilişkin sonuçların verildiği Tablo 4'e göre koyunkeçi işletmelerinin \%100'ünde kapalı tip ağıl kullanılmıştır. Elde edilen bu bulgu Günal'ın (2006) koyunculuk işletmelerinin \%55.5'inde kapalı tip ağıl, \%44.5'inde de açık tip ağıl bulgularıyla farklılık göstermektedir.

Tablo 4. İşletmelerin barınak özelliklerine ilişkin sonuçlar

Table 4. Findings for shelter characteristics of the enterprises

\begin{tabular}{llcc}
\hline & & $\mathrm{n}$ & $\%$ \\
\hline \multirow{2}{*}{ Barınak tipi } & Kapalı & 168 & 100.0 \\
& Yarı açık & 0 & 0 \\
\hline \multirow{4}{*}{ Barınak malzemesi } & Taş & 25 & 14.9 \\
& Kerpiç & 87 & 51.8 \\
& Briket & 56 & 33.3 \\
& Ahşap & 0 & 0 \\
\hline \multirow{3}{*}{ Barınak tabanı } & Beton & 29 & 17.3 \\
& Toprak & 139 & 82.7 \\
& Izgara & 0 & 0 \\
\hline \multirow{3}{*}{ Barınak çatı } & Kiremit & 0 & 0 \\
malzemesi & Toprak & 134 & 79.8 \\
& Sac örtü & 34 & 20.2 \\
\hline \multirow{2}{*}{ Doğum bölmesi } & Saz örtü & 0 & 0 \\
& Evet & 81 & 48.2 \\
& Hayır & 87 & 51.8 \\
\hline
\end{tabular}

Kolay temin edilebilmesi ve ekonomik olması nedeniyle ağıllarda temel yapı malzemesi olarak taş ve kerpiç ve son zamanlarda da briket kullanılarak inşa edilmiştir. Kapalı tip ağılların \%14.9'u barınak duvarı yapı malzemesi olarak taş, 51.8'inde kerpiç, \%33.3'ünde briket kullanılmıştır. Ele alınan işletmelerde temel yapı malzemesi olarak kerpiç kullanımı yüksek olmakla birlikte briket kullanımına yönelik bir geçiş gözlemler arasındadır. Koyun- keçi işletmeleri ağıllarının \%82.7'sinde zemin sert topraktan oluşmaktadır. Zemininde beton kullanılan ağılların oranı ise \%17.3'dür. Ağılların \% 79.8'inde çatı örtü malzemesi olarak toprak \%20.2'sinde sac (eternit) mevcuttur. Ağıl büyüklüğüne bağlı olarak ağıl içinde 
bir bölümü tahta çit ile ayırıp doğum bölmesi olarak kullanıldığı tespit edilmiştir. Doğum bölmesi olanların oranı \%48.2, doğum bölmesi olmayanların oranı \%51.8'dir. Karaca ve ark.'nın (1993) Van merkez ilçeye bağlı köylerde ağılların temel yapı malzemesi olarak kerpicin yaygın kullanıldığı, yapı malzemesi açısından araştırmamızla benzerlik göstermektedir. Elde edilen bu sonuçlar, Koyuncu ve ark.'nın (2006) Çanakkale'de yaptıkları çalışmada, keçi barınaklarının \%65'nin kapalı, barınak yapımında en fazla kullanılan malzemenin (\%79) tuğla-beton, ağıl zeminlerinin \%88.2'sinde toprak, \%11.7'sinde beton kullandığ 1 bulgularına göre farklılık göstermektedir. Bu durum işletmelerin farklı bölgelerde farklı ögreti ve imkanlara sahip olmasıyla açıklanabilir.

Koyuncu ve ark. (2006) Çanakkale koyun ve keçi yetiştiricileri birliği üyesi keçicilik işletmelerinin teknik sorunlarının belirlenmesi üzerine yaptıkları araştırmaya göre yetiştiricilerin ortalama yaşının 47, ortalama sürü büyüklüğünün 55.7 baş, ortalama ikizlik oranının \%0.59 olduğunu belirtmektedirler.

Aygün ve Sezgin (2009) Bitlis İlinde göçer ailelerin küçükbaş hayvancıllk faaliyetleri adlı yüksek lisans tez çalışmasında; göçer aile reislerinin ortalama yaşının 44, yaşça büyük olan aile reislerinin eğitim durumunun yaşça küçük olanlara göre düşük olduğu, göçer ailelerin gelir kaynağını koyun-keçi satışından elde ettikleri paranın oluşturduğu, koyun sayısının artışına paralel gelirlerinin de arttığı, ailelerin tamamının melez genotipli koyun ve k1l keçisi beslediği tespit edilmiştir.

Dayan (2007) Norduz koyun yetiştiriciliği yapılan işletmelerin yapısal özelliğini ortaya koymak için yapmış olduğu çalışmada; bölge koyunculuğu, iklim koşulları, topoğrafik yapı ve yetiştiricilerin eğitim düzeylerinden dolayı geleneksel yapısını devam ettirdiği bildirmektedir.

\section{İşletmelerin Genel Sorunları ve Beklentiler}

İşletmelerin Küçükbaş yetiştiricilikten memnun olma durumu, küçükbaş hayvancıllğın ya da büyükbaş hayvancılığın ikisinden hangisinin daha ekonomik olduğu durumu, yetiştiricilik yapma nedeni ve örgütlenme durumuna ilişsin sonuçlar Tablo 5'de verilmiştir.

Buna göre \%70.2 oranında koyun-keçi yetiştiriciliği \%21.4 oranında büyükbaş hayvancılığın daha ekonomik olduğu sonucu anlaşılmıştır. Küçükbaş hayvancılığının daha ekonomik olma durumunun (\%47.0 oranında) yem kaynağının büyük oranda meralara bağlı olmasından kaynaklandığ 1 yetiştiriciler tarafindan bildirilmiştir.

İşletmelerin koyun keçi yetiştiriciliğinde memnun olma durumunu irdelemek için ankette sorulan sorulara verilen cevaba göre; işletmelerin \%54.8 oranında koyun keçi yetiştiriciliği dışında herhangi bir işte çalışma imkanı bulduğunda hayvancılığa devam etmeyi düşünmediğini bildirmekte, geri kalan kesimin ise başka bir işte çalışan ve bu işi ek iş ya da hobi olarak yapanlarla küçükbaş hayvancılığa gönül vermiş kişiler olduğu tespit edilmiştir.

Üreticilerin \%81'inin tarım dışında çalışmadığı, \%19'unun ise tarım dışında sigortalı işte çalıştı̆̆ saptanmıştır. Araştırmada, köyler genelinde incelenen küçükbaş hayvancılık işletmelerinin \% 74.4'ü bir yetiştirici örgütüne üye olduklarını bildirirken, \%25'i herhangi bir yetiştirici örgütüne üye olmadıklarını bildirmişlerdir. Herhangi bir yetiştiricilik örgütüne üye olmayanlardan \%15.5'i üyeliğe sicak bakmakta, \%11.3'ü ise hiçbir şekilde üyeliği düşünmemektedir (Tablo 5). 
Tablo 5. İşletmelerin genel sorunları

Table 5. General problems of the enterprises

\begin{tabular}{llcc}
\hline & & $\mathrm{n}$ & $\%$ \\
\hline $\begin{array}{l}\text { Hangi hayvancılık faaliyeti daha } \\
\text { ekonomik }\end{array}$ & Küçükbaş & 118 & 70.2 \\
& Büyükbaş & 36 & 21.4 \\
\hline $\begin{array}{l}\text { Küçükbaş ya da büyükbaş } \\
\text { hayvancılığın ekonomik olma }\end{array}$ & Yem masrafı az & 79 & 47.0 \\
sebebi & $\begin{array}{l}\text { Birim canlı hayvan } \\
\text { verimi yüksek }\end{array}$ & 32 & 19.0 \\
& $\begin{array}{l}\text { Sürü büyütme ve } \\
\text { çoğaltma kolay }\end{array}$ & 13 & 7.7 \\
\hline Farklı iş imkanı olsa koyun-keçi & Bakımı kolay, iş yükü az & 29 & 17.3 \\
yetiştiriciliğini bırakma durumu & Evet & 92 & 54.8 \\
\hline $\begin{array}{l}\text { Küçükbaş hayvancılık dışında } \\
\text { çalışma durumu }\end{array}$ & Eayır & 76 & 45.2 \\
\hline Yetiştirici örgütlerine üyelik & Hayır & 32 & 19.0 \\
durumu & Evet & 136 & 81.0 \\
\hline $\begin{array}{l}\text { Yetiştirici örgütlerine üye } \\
\text { olmayanların istekliliği }\end{array}$ & Evet & 125 & 74.4 \\
\hline
\end{tabular}

Van İlinde yapılan bu çalışmada işletmelerinin \%81'inin tek geçim kaynağının küçükbaş hayvancılık olduğu ve başka bir geçim kaynağı olmadığ belirlenmiştir. İşletmelerin yarıdan fazlası farklı bir iş imkânı olduğu takdirde hayvancılıkla uğraşmayacaklarını bildirmişlerdir. Bu sonuç, Dellal ve ark.'nın (2002a) GAP Bölgesindeki koyun ve keçi işletmelerin \%84.9'unun tek geçim kaynağının bu üretim kolu olduğunu belirttikleri çalışmayla benzerlik göstermektedir.

İşletme sahiplerinin beklentilerini gösteren Tablo 6'da da görüldüğü gibi, incelenen işletmelerde başlıca hayvan hastalıklarıyla mücadelede sıkıntı yaşandığ 1 için veteriner hizmetlerine ihtiyaç duydukları, damızlık hayvan açığının olduğu, kredi ve kaçak hayvan girişinin önlenmesi gibi beklentilerinin olduğu belirlenmiştir.

İşletmecilerin yetkililerden beklentilerde veterinerlik hizmetleri \%36.9 ile ilk sırada gelmektedir. Bunu \%19 damızlık hayvan ihtiyacı, kredi \%17 ve \%3 kaçak hayvan girişi sorunlarının çözülmesi izlemektedir. İncelenen İşletmelerin \%10.7'sinde hiçbir beklentileri olmadığını belirtmişlerdir. Veterinerlik hizmetleri ihtiyacının giderilmesi ile ilgili beklentilerin başında, devletin tüm aşılamaları ve tedavileri ücretsiz ve sürekli yaptırmaları şeklinde gelmektedir. Kredi sağlanması ilgili problemin çözümünde ise kredilerin zamanında, koşulsuz ve sıfır faizli geri ödenmesi şeklinde bir talep söz konusudur. Dellal ve ark.'nın (2002a) GAP Bölgesindeki çalışmalarında yetiştiricilerin karlı bir hayvancılık için \%64.2"si kendilerine yem ve damızlık temini için ucuz kredi verilmesini, \%54.9'u mera alanları ve yem bitkisi üretiminin artırılmasını, \%22'si ürünlerin pazarlama fiyatı artırılmasını istediklerini bildirmişlerdir. 
Tablo 6. İşletme sahiplerinin beklentileri

Table 6. Expectations of farm owners

\begin{tabular}{llcc}
\hline & & $\mathrm{n}$ & $\%$ \\
\hline & Kredi & 29 & 17.3 \\
& Kredi -Veterinerlik hizmeti -Damıllk hayvan & 6 & 3.6 \\
& Kredi- Veterinerlik hizmeti -Damılık hayvan -Kaçak & 2 & 1.2 \\
& hayvan girişinin önlenmesi & 3 & 1.8 \\
& Kredi damılık hayvan & 2 & 1.2 \\
& Kredi kaçak hayvan girişinin önlenmesi & 62 & 36.9 \\
Yetkililerden & Veterinerlik hizmeti & 6 & 3.6 \\
& Veterinerlik hizmeti-Damılık hayvan & 1 & 0.6 \\
& Veterinerlik hizmeti- Kaçak hayvan girişinin & & \\
& önlenmesi & 32 & 19.0 \\
& Damılık hayvan & 1 & 0.6 \\
& Damılık hayvan -Kaçak hayvan girişinin önlenmesi & 5 & 3.0 \\
& Kaçak hayvan girişinin önlenmesi & 18 & 10.7 \\
\hline
\end{tabular}

Araştırmanın yürütüldüğü küçükbaş hayvancılık işletmelerinin \%74.4’ünün damızlık koyun-keçi birliğine üye oldukları, \%25'inin, herhangi bir yetiştirici örgütüne üye olmadıkları belirlenmiştir. Dellal ve ark. (2002a) küçükbaş hayvancılık işletmelerinin \%92.8'inin herhangi bir yetiştirici örgütüne üye olmadığı, daha kârlı bir koyun ve keçi yetiştiriciliği için örgütlenmenin yaygınlaştırılmasının önemli bir uygulama olduğuna vurgu yapılmıştır. Türkiye'de kamunun dişında hayvan yetiştiricilerinin ekonomik ve teknik örgütlenmede yetersiz olduğu, ekonomik anlamdaki örgütlenmenin üretim ve pazarlamadaki payının düşük olduğu, teknik örgütlenmenin ise daha başlangıçta olduğu bildirilmektedir (Kaymakçı ve ark. (2004). Bununla birlikte son yıllarda önemli adımlar atılmış ve örgütlenme konusunda yeni birliklerin kurulması gelecek için önemli kazanımlar elde edileceğini göstermiştir.

Türkiye'de koyun ve keçi yetiştiriciliğindeki örgütlenme eksikliği, yetiştiricilerin; ürünlerin satışı aşamasında ve girdilerin temininde pazarlık güçlerinin yetersiz kalmasına neden olmaktadır. Bu şekilde yetiştiriciler elde ettiği ürünleri düşük fiyatla satmakta, girdileri ise yüksek fiyatlarda temin etmektedir (Anonim, 2001). Bu nedenle, gerek hayvancilik politikalarının oluşturulmasında etkin olmak ve gerekse daha kârlı bir koyun ve keçi yetiştiriciliği için son derece önemli olan yetiştirici örgütlerinin bu şekilde yaygınlaştırılması önemli bir uygulama olacaktır. 2001 yılında çıkarılan 4631 Sayılı Hayvan Islahı Kanunu ve bu kanunun ilgili maddeleri gereğince 2001 yılında yayımlanan Islah Amaçlı Yetiştirici Birliklerinin Kurulması ve Hizmetleri Hakkında Yönetmelik küçükbaş yetiştiriciliği için yeni bir dönemi başlatmıştır. Dünyanın ileri ülkelerinde yetiştirici örgütleri üyelerinin sorunlarını çözmede, iyi kalite damızlık temin etmede, damızlık hayvanlarını değerlendirmede, ürünlerini değer fiyata satmada, girdileri kaliteli ve ucuza satın almada, devletin destekleme politikalarını oluşturmada çok etkin olmuşlar ve olmaya da devam edeceği bildirilmektedir (Vural ve Fidan, 2007; Gürsoy, 2009). Tarım ve Orman Bakanlığı'nın Damızlık Koyun-Keçi Birliği üyesi yetiştiricilere hayvan başına destekleme ödemesi yapıyor olması, yörede bu birliğe üyeliği artırmıştır. Van Damızlık Koyun-Keçi Yetiştiricileri Birliği 2006 yılında 
kurulmuştur. Bakanlar kurulunun 2006 tarihinde 1slah amaçlı yetiştirici birlikleri şeklinde örgütlenen ve damızlık kayıt sistemine kayıtlı olma şartı ile damızlık niteliği olan en az 25 baş anaç koyun veya keçiye sahip üreticiye hayvan başına destekleme ödemesi yapılacağına dair kararı, yetiştirici birliğindeki üye sayısını artırmıştır. Ankete katılanların \%74.4'ünün bir yetiştirici örgütüne üye oldukları saptanmıştır.

\section{Sonuç ve Öneriler}

Hayvancılığın, özelde küçükbaş hayvancılığın gelişebilmesi için her şeyden önce bu sektörde uğraşan üreticilerin gelir elde edebileceği cazip bir sektör haline getirilmesi gerekliliği göz ardı edilmemelidir. Ülkemiz koyunculuğunun tamamına yakını meraya dayalı olarak yapılmaktadır. Koyun yetiştiriciliğinin temeli olan çobanlık mesleğini özendirilmeli, yaşam şartları İyileştirilerek önlemler alınmalıdır. Özellikle çobanlık kursları düzenlenmeli, söz konusu kursları bitirenlere sertifika verilmelidir. Sağlık konusunda yetiştiriciler yeterince bilgilendirilmeli, özellikle yılın önemli bir kısmını merada geçiren koyunlar parazitler konusunda iyi incelenmeli ve gerekli koruyucu önlemler alınmalıdır.

Sonuç olarak, Van ili küçükbaş hayvancılığının nitelikleri ile genel sorunlarının belirlenmesi ve bölge küçükbaş hayvan üretim biçimlerinin tanımlanması amacıyla yapılan bu araştırmada, bölgede küçükbaş hayvancılığın ekstansif koşullarda, küçük aile işletmelerinde geleneksel bir yapıya bağlı olarak hem gelir getirici bir faaliyet hem de aile ihtiyaçlarına yönelik olarak yapıldığı tespit edilmiştir. Van ili toplam yüzölçümünün \%70’i çayır-meradır ve arazi koşulları özellikle koyun-keçi yetiştiriciliğine oldukça elverişlidir. Tüm olumsuzluklara rağmen, Van ili küçükbaş hayvan yetiştiriciliği potansiyeli göz önüne alınarak kamu ve yetiştiriciler, elbirliği ile geleneksel yapıda da olsa küçükbaş hayvan yetiştiriciliğinin cazip hale gelmesi ve sürdürülebilirliği konusunda gerekli girişimlerde bulunmaları gerekmektedir. Bölge yetiştiricilerinin temel hayvan yetiştirme konularında eğitilmesi ve işletme koşullarının iyileştirilmesi ile elde edilecek verimlerin artırılabileceği düşünülmektedir.

\section{Kaynaklar}

Aksoy, A., Yavuz, F., 2008. Hayvancılık işletmelerinin Avrupa Birliğine uyumu ve rekabet edebilirliği; Doğu Anadolu örneği. Tarım Ekonomisi Dergisi. 14(1): 37-45.

Anonim, 1998. Cumhuriyetin 75. Y1lında Van. Erk yayıncılık, Ankara. 461.

Anonim, 2020a. Türkiye istatistik yıllığ1. http://www.tuik.gov.tr, Türkiye İstatistik Kurumu, Ankara. Erişim tarihi: 04.07.2020.

Anonim, 2020b. Van rehberi. http://www.van.gov.tr/default_B0.aspx?content=1012. Van Valiliği, Van. Erişim tarihi: 23.12.2020.

Araç, B., 2007. Diyarbakır ili keçicilik işletmelerinin yapısal özellikleri. (Yüksek Lisans Tezi, basılmamış). Van Yüzüncü Yıl Üniversitesi, Fen Bilimleri Enstitüsü, Van.

Aygün, T., Sezgin, Y., 2009. Ülkemizde göçer küçükbaş hayvancılık faaliyetleri: Bitlis İli Örneği. 6. Ulusal Zootekni Bilim Kongresi, Atatürk Üniversitesi, Ziraat Fakültesi, Zootekni Bölümü, Erzurum, 24-26 Haziran 2009, s. 277-285.

Bilginturan, S., 2008. Burdur ili Damılık Koyun ve Keçi Yetiştiriciler Birliği üyesi 
işletmelerin yapısal özellikleri ve sorunları üzerine bir araştırma. (Yüksek Lisans Tezi, basılmamış) Süleyman Demirel Üniversitesi, Fen Bilimleri Enstitüsü, Isparta.

Dayan, Y.A., 2007. Norduz koyunu yetiştiriciliği yapılan kimi işletmelerin yapısal özellikleri (Yüksek Lisans Tezi, basılmamış). Van Yüzüncü Yıl Üniversitesi, Fen Bilimleri Enstitüsü, Van.

Dellal, G., Eliçin, A., Tekel, N., Dellal, İ., 2002a. GAP Bölgesinde küçükbaş hayvan yetiştiriciliğin yapısal özellikleri. . Tarımsal Ekonomi Araştırma Enstitüsü, Proje Raporu 2002-1, Yayın No, 82, TKB, Ankara.

Dellal, İ., Keskin, G., Dellal, G., 2002b . GAP Bölgesinde küçükbaş hayvan yetiştiren işletmelerin ekonomik analizi ve hayvansal ürünlerin pazara arzı. Tarımsal Ekonomi Araştırma Enstitüsü, Proje Raporu 2002-2, Yayın No, 83, TKB, Ankara.

Deniz, A., 2009. Hakkari ili merkez ilçede koyunculuk yapan işletmelerin ekonomik analizi (Yüksek Lisans Tezi, basılmamış). Van Yüzüncü Yıl Üniversitesi, Fen Bilimleri Enstitüsü, Van.

Günal, R., 2006. Tekirdağ ili merkez ilçeye bağlı köylerde bulunan koyun ağıllarının yapısal özelliklerinin belirlenmesi ve geliştirilebilme olanaklarının araştırılması. (Yüksek Lisans Tezi, basılmamış) Tekirdağ Üniversitesi, Fen Bilimleri Enstitüsü, Tekirdağ.

Gürsoy, O., 2009. Türkiye ve Avrupa Birliğinde küçükbaş hayvan yetiştiriciliğinde örgütlenme. Uludağ Üniversitesi, Ziraat Fakültesi Dergisi. 23(2): 79-95.

Karaca, O., Vanlı, Y., Kaymakçı, M., Altın T., Kaygısız, A. 1993. Doğu Anadolu Bölgesinde koyun yetiştirmenin sosyolojik ekonomik ve genetik görünüşü. No: 90.2F.071 No'lu Araştırma Fonu Proje Kesin Raporu, Yüzüncü Yıl Üniversitesi, Van.

Karaca, O., Aşkın, Y., Cemal, İ., Çivi, A., 1996. Doğu Anadolu göreneksel koyun yetiştirme sistemlerinin çağdaş 1slah programları bakımından potansiyelleri. Hayvancılık'96 Ulusal Kongresi, Bornova - İzmir, 18-20 Eylül 1996, s. 160- 168.

Kaymakçı, M., Karaca, O., Sönmez, R., 1998. Doğu Anadolu Bölgesi koyunculuğuna verilecek yön. Doğu Anadolu Tarım Kongresi Bildirileri, Erzurum, 14-18 Eylül 1998, s. 707-716.

Kaymakçı, M., Seymen, S., Taşkın, T., 2004. Damızlık Koyun-Keçi Yetiştiricileri Birlikleri'nin işlevleri. 4. Ulusal Zootekni Bilim Kongresi Bildirileri, Isparta, 01-03 Eylül 2004, s. 22-25.

Kaymakçı, M., 2006. İleri Koyun Yetiştiriciliği. Genişletilmiş 1. Baskı. Ege üniversitesi Basımevi, Bornova, İzmir, 365

Koyuncu M., Uzun, Ş.K., Tuncel, E., 2005. Güney Marmara Bölgesi keçicilik işletmelerinin genel durumu ve verim özelliklerinin belirlenmesi üzerine araştırmalar I. Keçicilik işletmelerinin genel durumu. Ankara Üniversitesi Ziraat Fakültesi Tarım Bilimleri Dergisi. 11(4): 374-378.

Koyuncu , E., Pala. A., Savaş. T., Konyalı. A., Ataşoğlu. C., Daş. G., Ersoy. İ. E., Uğur. F., Yurtman. İ.Y., Yurt. H. H., 2006. Çanakkale Koyun ve Keçi Yetiştiricileri Birliği üyesi keçicilik işletmelerinde teknik sorunların belirlenmesi üzerine bir araştırma. Hayvansal Üretim Dergisi. 47(1): 21-27.

SPSS, 2013. IBM SPSS Statistics 22.0 for Windows. Armonk, NY.

Vural, H., Fidan, H., 2007. Türkiye'de hayvansal üretim ve hayvancılık işletmelerinin özellikleri. Tarım Ekonomisi Dergisi. 13(2): 49-59. 